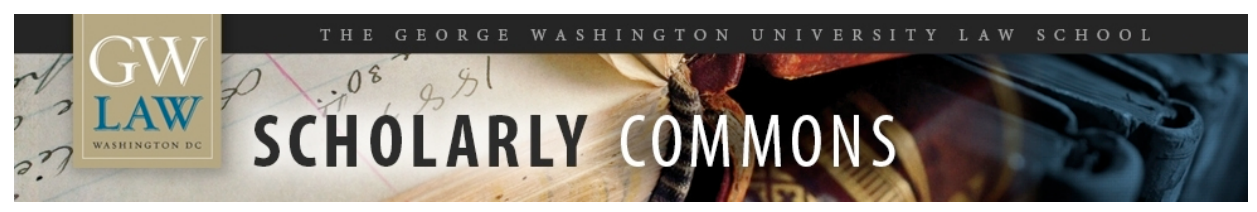

\title{
JUDGE BORK'S REMARKABLE ADHERENCE TO UNREMARKABLE PRINCIPLES OF NATIONAL SECURITY LAW
}

\author{
Gregory E. Maggs \\ George Washington University Law School, gmaggs@law.gwu.edu
}

Follow this and additional works at: https://scholarship.law.gwu.edu/faculty_publications

Part of the Law Commons

\section{Recommended Citation}

Maggs, Gregory E., Judge Bork's Remarkable Adherence to Unremarkable Principles of National Security Law (2015). 13 Ave Maria L. Rev. 5-19 (2015); GWU Law School Public Law Research Paper No. 2015-24; GWU Legal Studies Research Paper No. 2015-24. Available at SSRN: http://ssrn.com/abstract=2630623

This Article is brought to you for free and open access by the Faculty Scholarship at Scholarly Commons. It has been accepted for inclusion in GW Law Faculty Publications \& Other Works by an authorized administrator of Scholarly Commons. For more information, please contact spagel@law.gwu.edu. 


\title{
JUDGE BORK'S REMARKABLE ADHERENCE TO UNREMARKABLE PRINCIPLES OF NATIONAL SECURITY LAW
}

\author{
Gregory E. Maggs ${ }^{\dagger}$
}

\section{INTRODUCTION}

The late Judge Robert $\mathrm{H}$. Bork is usually remembered as an eminent jurist and scholar in the fields of antitrust law and constitutional law. His judicial opinions and his writings, especially The Antitrust Paradox ${ }^{1}$ and The Tempting of America, ${ }^{2}$ are certainly standards in these areas. Judge Bork, however, also deserves acclaim for his contributions to other fields of law. One extremely important subject, in which Judge Bork's judicial work has received little attention, is the law pertaining to national security and U.S. foreign relations.

This essay discusses Judge Bork's opinions in four important D.C. Circuit cases: Demjanjuk v. Meese, ${ }^{3}$ Persinger v. Islamic Republic of Iran, ${ }^{4}$ Finzer v. Barry, ${ }^{5}$ and Tel-Oren v. Libyan Arab Republic. ${ }^{6}$ In these cases, Judge Bork identified and followed nine very traditional principles of law concerning national security and foreign relations. These principles were so clear and well-established that at the time they seemed unremarkable. Indeed, while scrutinizing nearly every other aspect of Judge Bork’s records,

† Professor of Law and Co-Director of the National Security and U.S. Foreign Relations Law LL.M. program at the George Washington University Law School. I worked for Judge Bork at the American Enterprise Institute in 1990 and 1991, and stayed in close personal and professional contact with him after that. I am very grateful to the editors for dedicating this special issue to his memory. In my capacity as an officer in the U.S. Army Reserve, I worked on a number of the legal issues discussed in this article. The views expressed here are my own, and do not necessarily reflect those of the Army or the Department of Defense.

1. Robert H. Bork, The Antitrust Paradox: A Policy at WAR With ItSelf (1978).

2. Robert H. Bork, The Tempting OF AMERICA: THe Political SEduction of the LAW (1990).

3. Demjanjuk v. Meese, 784 F.2d 1114 (D.C. Cir. 1984).

4. Persinger v. Islamic Republic of Iran, 729 F.2d 835 (D.C. Cir. 1984).

5. Finzer v. Barry, 798 F.2d 1450 (D.C. Cir. 1986), aff'd in part, rev'd in part sub nom. Boos v. Barry, 485 U.S. 312 (1988).

6. Tel-Oren v. Libyan Arab Republic, 726 F.2d 774, 798 (D.C. Cir. 1984) (Bork, J., concurring). 
proponents and opponents of his nomination to the Supreme Court said very little about his opinions in these cases.

How Judge Bork addressed the law in the area of national security and U.S. foreign relations is a subject that deserves a fresh look in light of important Supreme Court litigation arising out of the War on Terror. In a series of cases, often decided by the narrowest of margins, Justices of the Supreme Court have effectively rejected each of the nine traditional principles that Judge Bork applied in his D.C. Circuit opinions. Contrasting the Supreme Court's controversial decisions in these cases to Judge Bork's very different and more restrained approach reveals another aspect of what was lost when the Senate failed to confirm Judge Bork's nomination to the Supreme Court in 1987.

\section{Four CASES AND NINE PRINCIPLES OF NATIONAL SECURITY AND FOREIGN RELATIONS LAW}

In 1986, the U.S. Court of Appeals for the D.C. Circuit decided the case of Demjanjuk v. Meese. ${ }^{7}$ In that case, an accused Nazi war criminal filed a habeas petition seeking to block his extradition from the United States to Israel. ${ }^{8}$ Demjanjuk claimed that the extradition would violate the International Convention on the Prevention and Punishment of the Crime of Genocide. ${ }^{9}$ In his opinion for the court, Judge Bork rejected the petitioner's claim for three reasons. First, the cited Genocide Convention had not yet become binding on the United States. ${ }^{10}$ Although the U.S. Senate had approved the treaty, the United States had not yet deposited the formal instrument of ratification, and the treaty by its terms did not become effective until ninety days after ratification. ${ }^{11}$ Second, the treaty was not self-executing, and Congress had not enacted any implementing legislation. ${ }^{12}$ Third, the treaty addressed extradition only for the crime of genocide, and Demjanjuk was being extradited to stand trial for murder and

7. Demjanjuk, 784 F.2d 1114.

8. Id. at 1115; see also United States v. Demjanjuk, 518 F. Supp. 1362 (N.D. Ohio 1981) (providing additional background).

9. See Demjanjuk, 784 F.2d at 1115-16 (referring to the Convention on the Prevention and Punishment of the Crime of Genocide).

10. Id.

11. Id. at 1116-17. See also Convention on the Prevention and Punishment of the Crime of Genocide, Dec. 9, 1948, 78 U.N.T.S. 277, available at https://reaties.un.org/doc/Publication/MTDSG/ Volume\%20I/Chapter\%20IV/IV-1.en.pdf (the United States ultimately ratified the Convention on Nov. 25,1988 , subject to various reservations).

12. Demjanjuk, 784 F.2d at 1116. 
malicious wounding, not genocide. ${ }^{13}$ "Since genocide is not the basis for this extradition," Judge Bork wrote, "the Genocide Convention, even if it were now law, would be irrelevant."14

In this case, Judge Bork recognized and applied three fundamental principles concerning national security and U.S. foreign relations, which might be summarized as follows:

(1) A treaty does not bind the United States if the United States has not ratified it.

(2) Even if a treaty is in effect, courts can enforce the treaty's requirements only if the treaty is self-executing or if Congress has implemented the treaty through legislation.

(3) A treaty must be interpreted according to the ordinary meaning of its terms.

At the time of the Demjanjuk decisions, these principles were wellestablished and generally uncontroversial. Principles (1) and (3) came straight from the Restatement (Second) of Foreign Relations Law. ${ }^{15}$ Section 139 of that work says: "An international agreement does not, per se, impose an obligation upon a state not a party to it without the consent of that state."16 Section 147(1)(a) instructs that treaties be interpreted by "the ordinary meaning of the words of the agreement in the context in which they are used" in addition to other factors. ${ }^{17}$ The Restatement (Third) of Foreign Relations Law, published the year following the Demjanjuk decision, only slightly rephrases these points. ${ }^{18}$ Principle (2) comes directly from the Supreme Court's well-known 1888 decision in Whitney v. Robertson, which held that when treaty "stipulations are not self-executing, they can only be enforced pursuant to legislation to carry them into effect...."19 Because Judge Bork followed these principles so clearly in Demjanjuk and because the principles themselves were not particularly remarkable, no one said much about them

13. Id. at 1117.

14. Id.

15. RESTATEMENT (SECOND) OF FOREIGN RELATIONS LAW (1965).

16. Id. § 139 .

17. Id. § 147(a)(1).

18. Restatement (Third) OF Foreign Relations LAW § 324 (1987) (“An international agreement does not create either obligations or rights for a third state without its consent.”); § 325(1) (“An international agreement is to be interpreted in good faith in accordance with the ordinary meaning to be given to its terms in their context and in the light of its object and purpose.").

19. Whitney v. Robertson, 124 U.S. 190, 194 (1888). 
during the debates regarding Judge Bork's subsequent nomination to the Supreme Court.

A second illustrative D.C. Circuit decision is Persinger v. Islamic Republic of Iran. ${ }^{20}$ Marine Sergeant Gregory Persinger was one of the U.S. embassy guards taken hostage in Tehran in 1979. After his release, he and others sued the government of Iran, seeking damages for their detention and maltreatment. ${ }^{21}$ In his opinion for the court, Judge Bork did not allow the case to proceed. However sympathetic and meritorious the plaintiffs' grievances against Iran may have seemed, Judge Bork concluded that the court lacked jurisdiction because a federal statute said: "[A] foreign state shall be immune from the jurisdiction of the courts of the United States."22 The statute contained an exception for injuries caused within the United States. ${ }^{23}$ But Judge Bork concluded that the U.S. embassy in Tehran was not "within the United States," even though the United States asserts jurisdiction over its embassies for some purposes. ${ }^{24}$

The Persinger decision exemplifies two additional principles of law concerning national security and U.S. foreign relations, which might be summarized in this way:

(4) Although Congress may have power to regulate matters occurring outside the United States, federal statutes may specify that Congress has not done so.

(5) U.S. installations outside of the United States are not within the territory of the United States, even if the United States exercises control over them.

Each of these principles, like the previous three discussed above, were well-established and uncontroversial at the time of the decision. Citing older precedent, the Supreme Court concisely summarized principle (4) just a short time after the D.C. Circuit's decision in the Persinger case as follows: "Congress has the authority to enforce its laws beyond the territorial boundaries of the United States. ... Whether Congress has in fact exercised that authority in [particular] cases is a matter of statutory construction.,25

\footnotetext{
20. Persinger v. Islamic Republic of Iran, 729 F.2d 835 (D.C. Cir. 1984).

21. Id. at 837.

22. Id. at 838 (emphasis omitted) (quoting 28 U.S.C. § 1604 (1976)).

23. Id. (citing 28 U.S.C. § 1605(a)(5) (1976)).

24. Id. at 839.

25. E.E.O.C. v. Arabian Am. Oil Co., 111 S. Ct. 1227, 1230 (1991) (alteration in original) (citing Foley Bros., Inc. v. Filardo, 336 U.S. 281, 284-85 (1949); Benz v. Compania Naviera Hidalgo, S.A., 353 U.S. 138, 147 (1957)).
} 
Principle (5) underlay the Supreme Court's decision in cases like Johnson $v$. Eisentrager which held that an enemy prisoner held by the United States in a U.S. military prison in occupied Germany after World War II was not in the territory of the United States. ${ }^{26}$

A third D.C. Circuit case in which Judge Bork wrote the court's opinion was Finzer v. Barry. ${ }^{27}$ In that case, Father David Finzer and other anticommunist activists wanted to protest in front of the Soviet and Nicaraguan embassies in Washington, D.C. ${ }^{28}$ They challenged a D.C. statute that prohibited displaying placards within 500 feet of any embassy if the display would "bring into public odium" the government of any foreign country. ${ }^{29}$ The plaintiffs claimed that the statute violated the First Amendment because the prohibition on displaying placards was content-based, viewpointdiscriminatory, vague, and overbroad. ${ }^{30}$

Judge Bork rejected these arguments. Later, some of what Judge Bork wrote about the First Amendment was reversed by the Supreme Court. ${ }^{31}$ But Judge Bork's opinion for the D.C. Circuit is still significant because it applied two fundamental principles for deciding national security and U.S. foreign relations law cases that at least, in the abstract, were not controversial at the time of the case. The plaintiffs' First Amendment challenge to the statute required the court to determine whether the government had a compelling interest for its speech limitations. ${ }^{32}$ The government argued that the statute was necessary for national security based on the logic that how the United States protects foreign embassies in Washington influences how foreign countries protect U.S. embassies abroad. ${ }^{33}$ In evaluating this argument, Judge Bork observed that Congress had power to define and punish crimes against the law of nations under Article I, Section 8 of the Constitution. $^{34}$ He then looked to the Federalist Papers and other historic documents to determine what this power originally was meant to embrace. ${ }^{35}$ Judge Bork concluded that "the framers understood that the protection of

26. Johnson v. Eisentrager, 339 U.S. 763, 768 (1950) (concluding that the alien enemy "at no relevant time and in no stage of his captivity, has been within [the United States'] territorial jurisdiction”).

27. Finzer v. Barry, 798 F.2d 1450 (D.C. Cir. 1986), aff'd in part, rev'd in part sub nom. Boos v. Barry, 485 U.S. 312 (1988).

28. Id. at 1452 .

29. Id. (quoting D.C. CODE § 22-1115 (1981)).

30. Id. at 1470 .

31. See Boos v. Barry, 485 U.S. 312, 329 (1988) (holding that D.C. CoDE § 22-1115 violates the First Amendment).

32. Finzer, 798 F.2d at 1458.

33. Id. at 1462.

34. Id. at 1454 (citing U.S. ConST. art. I, § 8, cl. 10).

35. Id. at 1457 (citing THE FEDERALIST No. 3 (John Jay)). 
foreign embassies from insult was one of the central obligations of the law of nations." 36 This factor counted strongly in favor of the law. In addition, Judge Bork said that courts must defer to the political branches in cases involving foreign affairs. ${ }^{37}$ Accordingly, Judge Bork agreed that the government had a compelling interest for the restrictions. ${ }^{38}$

In this decision, we can see two additional principles of national security and foreign relations law, which might be summarized as follows:

(6) History should guide courts in answering difficult questions about the scope of the U.S. government's power over foreign affairs.

(7) Courts traditionally defer to the President and Congress on issues concerning foreign policy.

Although disagreements may arise about the application of these principles in particular cases, the principles themselves were at the time rather unremarkable. A well-known example of principle (6) appears in Reid $v$. Covert, a case that considered the United States' "entire constitutional history and tradition" when confronted with the question whether treaties were subject to limitations of the Constitution. ${ }^{39}$ For principle (7), Judge Bork relied on Regan $v$. Wald, which emphasized the "classical deference [owed by courts] to the political branches in matters of foreign policy."40

A fourth D.C. case in which Judge Bork wrote an opinion is Tel-Oren v. Libyan Arab Republic. ${ }^{41}$ That litigation arose out of a horrific 1978 terrorist attack on a bus in Israel which killed dozens and seriously wounded even more. $^{42}$ The plaintiffs were some of the victims or their representatives. ${ }^{43}$ They sued the Palestine Liberation Organization and other defendants who allegedly orchestrated the attacks. ${ }^{44}$ They claimed violations of several treaties, including the Geneva Conventions of 1949, the Hague Conventions on the Law of War, and the 1977 Protocols to the Geneva Conventions. ${ }^{45}$ Judge Bork and the two other judges on the panel all agreed the lawsuit

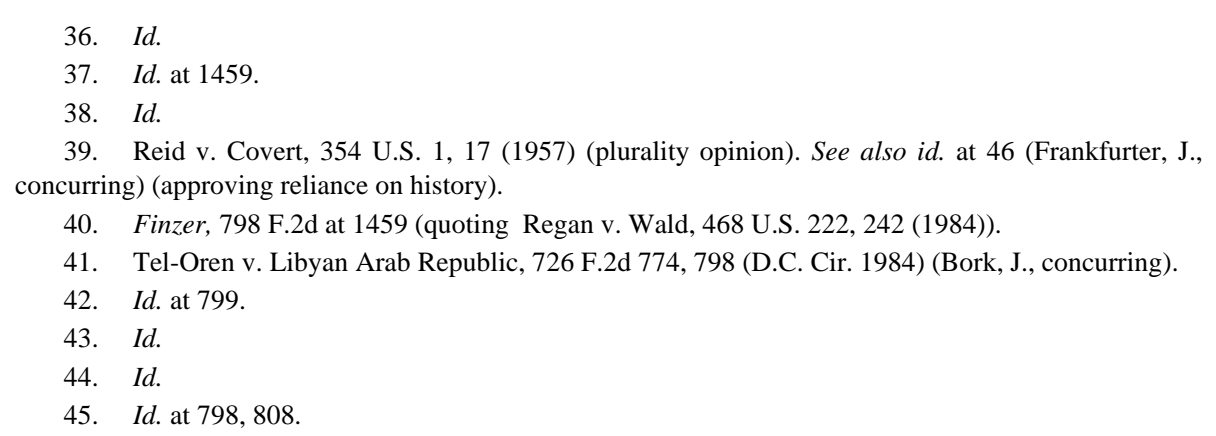


should be dismissed. ${ }^{46}$ But they could not agree on the reason. The judges accordingly issued a very brief per curiam opinion announcing the judgment. They each then wrote separate opinions concurring in the judgment. ${ }^{47}$

Judge Bork made several notable points in his separate opinion. First, he asserted that the plaintiffs had failed to state a cause of action. ${ }^{48}$ He reasoned that the Geneva Conventions, the Hague Convention, and the other cited treaties did not create one because these treaties required implementing legislation, and Congress had not passed a statute giving individuals rights that they could enforce in court. ${ }^{49}$ Judge Bork also observed that these treaties mostly regulated the treatment of prisoners captured in a war. Allowing such prisoners to bring lawsuits, he reasoned, could not have been intended because there could be thousands of lawsuits filed by prisoners of war "who might think their rights under the ... Conventions violated in the course of any large-scale war." ${ }^{\text {"No }}$ Judge Bork said those lawsuits might be beyond the capacity of the legal system to resolve and innumerable private suits at the end of a war might be an obstacle to peace. ${ }^{51}$ Second, Judge Bork observed that the 1977 Protocols to the Geneva Convention were not binding on the United States because the United States had not ratified these Protocols. ${ }^{52}$ Third, based on separation of powers concerns, Judge Bork rejected the view that "federal common law automatically provides a cause of action for international law violations, as it would for violations of other federal common law rights." 53

Judge Bork's opinion adhered to two of the principles of law previously mentioned: treaties do not bind the United States if they have not yet been ratified and that implementing legislation may be needed to supply rights to individuals. In addition, Judge Bork also followed two additional principles, both of which involve judicial restraint:

(8) Treaties should not be construed to produce intolerable results that could not have been intended (e.g., innumerable lawsuits by prisoners captured in a war).

\footnotetext{
46. Id. at 775 (per curiam).

47. See id. at 775 (Edwards, J., concurring); id. at 798 (Bork, J., concurring); id. at 823 (Robb, J., concurring).

48. Id. at 801 (Bork, J., concurring).

49. Id. at 809 .

50. Id. at 810 .

51. Id.

52. Id. at 808-09.

53. Id. at 810 .
} 
(9) Separation of powers concerns should limit judicial innovation in matters that concern foreign affairs.

These principles, like the others previously identified, were at the time, unremarkable. The Supreme Court followed principle (8) just a few years later in Chan v. Korean Air Lines, Ltd., indicating that absurd interpretations of a treaty must be dismissed. ${ }^{54}$ Principle (9) found expression in Harisiades v. Shaughnessy, where the Supreme Court said:

[A]ny policy toward aliens is vitally and intricately interwoven with contemporaneous policies in regard to the conduct of foreign relations, the war power, and the maintenance of a republican form of government. Such matters are so exclusively entrusted to the political branches of government as to be largely immune from judicial inquiry or interference. ${ }^{55}$

Critics of Judge Bork disagreed with other aspects of his jurisprudence during his confirmation hearing. Yet they said little about these nine general principles. In retrospect, however, as events have unfolded, Judge Bork's adherence to these nine principles is quite noteworthy because jurists who were appointed to the Supreme Court after the Senate chose not to confirm Judge Bork decided to take a very different approach in cases raising extremely important legal issues in the fields of national security and U.S. foreign relations.

\section{THE SUPREME COURT's DEPARTURE FROM THE PRINCIPLES FOLLOWED BY JUDGE BORK}

Since September 11, 2001, the United States has been engaged in a global war on terror. The war has spilled significant American blood and cost great treasure. It also may have produced more Supreme Court litigation than any war in history. Most notably, over the past decade, the Supreme Court decided four important cases concerning the rights of detained enemies. In Hamdi v. Rumsfeld, ${ }^{56}$ the Court held that the Due Process clause required an independent tribunal to determine whether prisoners are properly classified as detainable enemy combatants. ${ }^{57}$ In Rasul v. Bush, ${ }^{58}$ Hamdan v.

\footnotetext{
54. Chan v. Korean Air Lines, Ltd., 490 U.S. 122, 134 (1989).

55. Harisiades v. Shaughnessy, 342 U.S. 580, 588-89 (1952).

56. Hamdi v. Rumsfield, 542 U.S. 507 (2004) (plurality opinion).

57. Id. at 509 .

58. Rasul v. Bush, 542 U.S. 466 (2004).
} 
Rumsfeld, ${ }^{59}$ and Boumediene v. Bush, ${ }^{60}$ the Court held that the federal courts had habeas corpus jurisdiction over the detainees held at Guantanamo Bay, Cuba. In Hamdan, the Court also struck down the use of military commissions - as they were then constituted - to try enemy combatants for war crimes. ${ }^{61}$ In each of these cases, a majority or plurality of the Supreme Court effectively rejected one or more of the nine basic principles that Judge Bork followed.

Principle (1), described above, was that treaties do not bind the United States until the United States ratifies them and they become effective. The plurality opinion in Hamdan, however, did not follow this principle. Instead, the plurality opinion concluded that military commissions did not satisfy one of the guarantees in Protocol I of 1977 to the Geneva Conventions. ${ }^{62}$ The plurality reached this conclusion even though it acknowledged that the United States had not ratified the Protocol. ${ }^{63}$ No crystal ball or vivid imagination is necessary for surmising how Judge Bork would have handled this issue; Judge Bork not only concluded that treaties are not effective until ratified in the Demjanjuk case, ${ }^{64}$ but also specifically rejected claims under Protocol I in the Tel-Oren decision. ${ }^{65}$

Principle (2) was that even if treaties are in effect, courts can enforce them only if they are self-executing or if Congress has implemented the treaties' terms through legislation. The Court in Hamdan, however, also did not follow this principle. It determined that a private litigation could assert that the Geneva Conventions constrained the President's war powers even though these conventions do not have applicable implementing legislation. ${ }^{66}$ This decision was remarkable because, as Justice Thomas pointed out in dissent, the Supreme Court previously had held in Johnson v. Eisentrager ${ }^{67}$

59. Hamdan v. Rumsfield, 548 U.S. 557 (2006) (plurality opinion).

60. Boumediene v. Bush, 553 U.S. 723 (2008).

61. Hamdan, 548 U.S. at 624.

62. Id. at 633 (Stevens., J.) (concluding that the procedures for military commissions which allowed exclusion of the accused from the courtroom when necessary to protect classified evidence violate a provision in Protocol I giving the accused a right to be present during trial).

63. Id. at 634. Justice Kennedy, who joined other portions of Justice Stevens's opinion, found it unnecessary to decide whether "Article 75 of Protocol I to the Geneva Conventions is binding law notwithstanding the earlier decision by our Government not to accede to the Protocol." Id. at 654 (Kennedy, J., concurring).

64. See Demjanjuk v. Meese, 784 F.2d 1114 (D.C. Cir. 1984).

65. Tel-Oren v. Libyan Arab Republic, 726 F.2d 774, 808-09 (D.C. Cir. 1984) (Bork, J., concurring).

66. Hamdan, 548 U.S. at 625-27.

67. Johnson v. Eisentrager, 339 U.S. 763 (1950). 
that the Geneva Convention did not create private rights. ${ }^{68}$ Again, the question of how Judge Bork would have handled the issue is not a mystery. In his Tel-Oren opinion, he concluded that the Geneva Conventions were not self-executing. ${ }^{69}$ Although the majority in Hamdan disagreed, the logic of Judge Bork's position was not lost on others. Just months after the Hamdan decision, in a bipartisan move, Congress promptly addressed the Supreme Court's deviation by declaring in the Military Commissions Act of 2006: "No alien unprivileged enemy belligerent subject to trial by military commission under this chapter may invoke the Geneva Conventions as a basis for a private right of action." ${ }^{70}$

Principle (3), described above, is that courts must interpret treaties according to their ordinary meaning. The Supreme Court also strayed from this principle in the Hamdan case when it concluded that a suspected al Qaeda conspirator had rights under common Article 3 of the Geneva Conventions. ${ }^{71}$ Common Article 3 applies to conflicts "not of an international character." "72 The Court concluded that the global war on terror was "not of an international character" because, among other factors, "the commentaries [to the Geneva Conventions] . . . make clear 'that the scope of application of the Article must be as wide as possible." "73 Justice Thomas's dissent disagreed, observing: "The conflict with al Qaeda is international in character in the sense that it is occurring in various nations around the globe." ${ }^{.74}$ It takes little speculation to imagine which interpretation of common Article 3 is more like Judge Bork's ordinary meaning interpretation of the treaty provision at issue in Demjanjuk.

Principle (4) was that, even though Congress may have power to regulate matters occurring outside the United States, federal statutes may specify that Congress has not exercised this power. The Supreme Court's antagonism toward this seemingly uncontroversial principle appeared in both the Rasul and Hamdan cases. In Rasul, the Court allowed detainees held at the Guantanamo Bay naval base to bring habeas corpus actions in federal court. ${ }^{75}$

68. Hamdan, 548 U.S. at 715-16 (Thomas, J., dissenting) (concluding that "both of Hamdan's Geneva Convention claims are foreclosed by Johnson v. Eisentrager" because responsibility for enforcement of the Conventions was committed to "political and military authorities" rather than the courts).

69. Tel-Oren, 726 F.2d at 809.

70. 10 U.S.C. § $948 b(e)$ (2014) (citations omitted).

71. Hamdan, 548 U.S. at 630.

72. Geneva Convention (III) Relative to the Treatment of Prisoners of War, art. 3, Aug. 12, 1949, 6 U.S.T. 3316 [hereinafter Geneva Convention (III)].

73. Hamdan, 548 U.S. at 631 (quoting Geneva Convention (III), cmt. 36).

74. Id. at 719 (Thomas, J., dissenting).

75. Rasul v. Bush, 542 U.S. 466, 483 (2004). 
The Court reasoned that the federal habeas statute allows a court to exercise jurisdiction over a habeas detainee if the detainee's custodian is within the court's jurisdiction. ${ }^{76}$ The Court recognized that its decision contradicted a key precedent, Johnson v. Eisentrager, which had interpreted the federal habeas corpus statute to require the detainee, rather than the custodian, to be within the court's jurisdiction (and which accordingly would have precluded jurisdiction over any detainees at Guantanamo Bay). ${ }^{77}$ The dissent in Rasul protested what it considered to be the overruling of Eisentrager ${ }^{78}$ Congress subsequently sided with the dissent and promptly responded by enacting the Detainee Treatment Act of $2005 .^{79}$ This Act, in unmistakable terms, specifies that: "no court, justice, or judge shall have jurisdiction to hear or consider ... an application for a writ of habeas corpus filed by or on behalf of an alien detained by the Department of Defense at Guantanamo Bay, Cuba ....”80 The government thought that this statute would put an end to the habeas litigation arising from Guantanamo. ${ }^{81}$ But in Hamdan, the Supreme Court concluded the Detainee Treatment Act did not apply to pending cases and thus did not preclude its exercise of jurisdiction. ${ }^{82}$ Justice Scalia's dissent criticized this decision, asserting that the majority had not respected Congress's choice with respect to the extraterritorial application of the habeas corpus statute to Guantanamo Bay. ${ }^{83}$ The dissent also observed that the Court's decision undermined the purpose of the Detainee Treatment Act because habeas corpus actions had already been filed on behalf of all Guantanamo detainees. ${ }^{84}$ As Justice Scalia put it: "The Court's interpretation transforms a provision abolishing jurisdiction over all Guantanamo-related habeas petitions into a provision that retains jurisdiction over cases sufficiently numerous to keep the courts busy for years to come." ${ }^{85} \mathrm{He}$ further asserted that the Court's interpretation also strayed from a firm tradition that amendments to jurisdictional statutes apply to pending cases. ${ }^{86}$

\footnotetext{
76. Id.

77. Id. at 479 (concluding that another precedent had already overruled Eisentrager).

78. Id. at 493 (Scalia, J., dissenting).

79. Detainee Treatment Act of 2005, Pub. L. No. 109-148, 119 Stat. 2739 (Dec. 30, 2005).

80. Id. § 1005, 119 Stat. 2739-2740 (codified as amended at 28 U.S.C. § 2241).

81. See Hamdan v. Rumsfield, 548 U.S. 557, 574-75 (2006).

82. Id. at $575-76$.

83. Rasul, 542 U.S. at 493 (Scalia, J., dissenting).

84. Hamdan, 548 U.S. at 669 (Scalia, J., dissenting) (noting that over 600 habeas petitions were pending, including one that covered all detainees at Guantanamo Bay).

85. Id.

86. Id. at 659-660 ("[The majority] cannot cite a single case in the history of Anglo-American law (before today) in which a jurisdiction-stripping provision was denied immediate effect in pending cases, absent an explicit statutory reservation.”).
} 
Based on what he said in Persinger, it takes little effort to imagine which view Judge Bork would have agreed with.

Principle (5) was that U.S. installations outside of the United States are not within the territory of the United States, even if the United States exercises control over them. In Boumediene, however, the Court reached the opposite conclusion. After the Court effectively nullified the Detainee Treatment Act of 2005 in Hamdan, a shocked Congress immediately responded by amending the federal habeas corpus statute. The amendment, passed by a bi-partisan vote, repeated the Detainee Treatment Act's prohibition on the exercise of habeas corpus jurisdiction over detainees at Guantanamo Bay and then said in unambiguous terms:

The amendment... shall take effect on the date of the enactment of this Act, and shall apply to all cases, without exception, pending on or after the date of the enactment of this Act which relate to any aspect of the detention, transfer, treatment, trial, or conditions of detention of an alien detained by the United States since September 11, $2001 .^{87}$

As Judge Randolph wrote in an opinion for the D.C. Circuit interpreting the amendment, "It is almost as if the proponents of these words were slamming their fists on the table shouting "When we say "all," we mean all—without exception!'”88 This amendment was so clear that it prevented the Supreme Court from concluding in Boumediene, as it had done in Rasul and Hamdan, that the habeas corpus statute provided jurisdiction. ${ }^{89}$ What the Court decided instead was that Congress violated the Constitution by depriving the federal courts of habeas corpus jurisdiction over detainees at Guantanamo Bay, Cuba, without formally suspending the writ of habeas corpus. ${ }^{90}$ The Court reasoned that the extensive U.S. control of the navy base made the base functionally the equivalent of U.S. territory. ${ }^{91}$ The dissent rejected this conclusion for a simple reason: "Guantanamo Bay lies outside the sovereign territory of the United States." "With which reasoning would Judge Bork, who concluded that U.S. embassies are not in the United States, have agreed?

Principle (6), described above, called for judges to rely on historic practice and precedent to resolve difficult questions about the power of the

87. Military Commissions Act of 2006, § 7(b), Pub. L. No. 109-366, 120 Stat 2600 (Oct. 17, 2006).

88. Boumediene v. Bush, 476 F.3d 981, 987 (D.C. Cir. 2007), rev'd, 553 U.S. 723 (2008).

89. Boumediene v. Bush, 553 U.S. 723, 736 (2008).

90. Id. at 771 .

91. Id. (holding that the habeas corpus suspension clause, art. I, § 9, cl. 2, "has full effect at Guantanamo Bay").

92. Id. at 832 (Roberts, C.J., dissenting). 
government over foreign affairs. In the recent War on Terror cases, the Supreme Court has given little weight to history and precedent. Consider just the Court's decision in Hamdan and all that Congress had to do subsequently to restore the law. In addition to the habeas corpus and Geneva Convention issues discussed above, the Court departed from history in three other ways. First, the Court concluded that the President did not have any specific statutory authorization under the Uniform Code of Military Justice (UCMJ) to use military commissions to try war crimes, ${ }^{93}$ even though the Supreme Court previously had held that a nearly identically worded provision of the predecessor law, the Articles of War, did give the President this authority. ${ }^{94}$ Congress responded to this holding by giving the President specific authority: "The President is authorized to establish military commissions under this chapter for offenses triable by military commission...."95 Second, the Court also concluded that the UCMJ required the procedural and evidentiary rules for military commissions to be "uniform insofar as practicable" with the rules for courts-martial. ${ }^{96}$ The Court ignored the history of this provision, which was to make procedures uniform not between courts-martial and military commissions but uniform among the various services in the Armed Forces. ${ }^{97}$ Congress responded to this holding by revising the UCMJ to say: "All rules and regulations made under this article shall be uniform insofar as practicable, except insofar as applicable to military commissions ...."98 Third, a plurality of the Supreme Court concluded that a conspiracy to commit violations of the law of war is not itself a violation of the law of war and that therefore such a conspiracy cannot be tried by a military commission absent additional Congressional authorization. ${ }^{99}$ This position is difficult to square with a long history of prior cases in which the defendants had been charged with conspiring to commit a violation of the law of war. ${ }^{100}$ In response to the plurality's conclusion,

93. Hamdan v. Rumsfield, 548 U.S. 557, 593 (2006) (plurality opinion).

94. Id. at 683 (Thomas, J., dissenting) (quoting Ex parte Quirin, 317 U.S. 1, 29 (1942)) (explaining that Uniform Code of Military Justice art. 21, 10 U.S.C. $§ 821$, is the successor to Article 15 of the Articles of War, which was held by the Supreme Court in Ex parte Quirin to "authoriz[e] trial of offenses against the law of war before [military] commissions”).

95. 10 U.S.C. $\S 948 b(b)$.

96. Hamdan, 548 U.S. at 622 (emphasis omitted) (interpreting Uniform Code of Military Justice art. 36(b), 10 U.S.C. § 836(b), prior to its subsequent amendment).

97. Id. at 711 (Thomas, J., dissenting) (citing the preamble of the Uniform Code of Military Justice and explaining that "[t]he vision of uniformity that motivated the adoption of the UCMJ, embodied specifically in Article 36(b), is nothing more than uniformity across the separate branches of the armed services”).

98. 10 U.S.C. § 836(b) (2014).

99. Hamdan, 548 U.S. at 611-12 (plurality).

100. Id. at 698 (Thomas, J., dissenting). 
Congress immediately made conspiracy a crime that is triable by military commission. ${ }^{101}$ The Supreme Court's ahistorical reasoning in Hamdan, simply put, is not the approach of Judge Bork in the Finzer case.

Principle (7) was that courts should defer to the President and Congress in matters of foreign policy. Perhaps the clearest departure from this principle occurred in Hamdi, where the Court refused to defer to the President's determination of who is an enemy combatant and who is not, requiring an independent tribunal to perform that function. ${ }^{102}$ Deference would have required a different result. As Justice Thomas put the matter in his dissent:

The Executive Branch, acting pursuant to the powers vested in the President by the Constitution and with explicit congressional approval, has determined that Yaser Hamdi is an enemy combatant and should be detained. This detention falls squarely within the Federal Government's war powers, and we lack the expertise and capacity to second-guess that decision. ${ }^{103}$

Judge Bork would have applied principle (7) in the same manner and reached the same conclusion.

Principle (8) was that treaties should not be construed to produce intolerable results that could not have been intended. The Supreme Court not only deviated from this principle but also allowed precisely the result that Judge Bork identified in Tel-Oren as being intolerable: innumerable lawsuits by prisoners captured in a war. ${ }^{104}$ In Hamdan, as discussed above, the Court allowed hundreds of cases by detainees to go forward with their claims under the Geneva Conventions. ${ }^{105}$

Principle (9) was that separation of powers concerns should limit judicial involvement in foreign affairs. As described above, in all of its decisions, the Supreme Court has disagreed with Congress and the President on how to conduct the War on Terror and substituted its own judgment for that of the elected political branches. Even when Congress responded with amended statutes, the Supreme Court repeatedly rejected the legislative will. Here, we do not need to speculate about what Judge Bork would have thought. In a 2005 essay, A War the Courts Shouldn't Manage, Judge Bork and his coauthor David B. Rivkin Jr., specifically criticized the courts for their

101. See 10 U.S.C. § 950t(29) (2014).

102. Hamdi v. Rumsfield, 542 U.S. 507, 533 (2004) (plurality opinion).

103. Id. at 579 (Thomas, J., dissenting).

104. Tel-Oren v. Libyan Arab Republic, 726 F.2d 774, 810 (D.C. Cir. 1984).

105. Hamdan, 548 U.S. at 669 (Scalia, J., dissenting). 
usurpation of the President's power. ${ }^{106}$ They explained the problem as follows: "Courts have neither the constitutional authority nor the expertise and information to override the president's determinations on issues such as whether we are in armed conflict or what kind of anti-terrorist cooperation we should engage in with foreign governments." ${ }^{107}$ This reasoning echoes what Judge Bork said in the 1980s in his four decisions regarding international law.

\section{CONCLUSION}

What should observers make of all of this? Judge Bork's rulings in the 1980s were unremarkable at the time. But they are remarkable now because what seemed uncontroversial in the 1980s has been so consistently rejected by the Supreme Court in the litigation arising out of the War on Terror. The cases discussed above show another aspect of what was lost when Judge Bork's confirmation struggle came out the wrong way. Judge Bork would have made a substantial contribution not only in constitutional law cases, but also in cases involving national security and U.S. foreign relations. I suspect that additional research would find many other areas, besides constitutional law and antitrust law, in which his exclusion from the Supreme Court had significant deleterious consequences.

106. Robert H. Bork \& David B. Rivkin Jr., A War the Courts Shouldn't Manage, WASH. Post, Jan. 21, 2005, at A17, available at http://www.washingtonpost.com/wp-dyn/articles/A25275-2005Jan20.html.

107. Id. 